\title{
Article \\ A Collaborative Model for Leadership Education in High-Potential University Women Students
}

\author{
Pilar Laguna-Sánchez (D), Mónica Segovia-Pérez (D), Concepción de la Fuente-Cabrero (D) and Ana M. Vargas-Pérez * \\ Business Administration Department, University Rey Juan Carlos, 28032 Madrid, Spain; \\ pilar.laguna@urjc.es (P.L.-S.); monica.segovia@urjc.es (M.S.-P.); concepcion.delafuente@urjc.es (C.d.1.F.-C.) \\ * Correspondence: ana.vargas@urjc.es
}

Citation: Laguna-Sánchez, P.; Segovia-Pérez, M.; Fuente-Cabrero, C.d.l.; Vargas-Pérez, A.M. A Collaborative Model for Leadership Education in High-Potential University Women Students. J. Open Innov. Technol. Mark. Complex. 2021, 7, 138. https://doi.org/10.3390/ joitmc7020138

Received: 24 April 2021

Accepted: 18 May 2021

Published: 20 May 2021

Publisher's Note: MDPI stays neutra with regard to jurisdictional claims in published maps and institutional affiliations.

Copyright: (C) 2021 by the authors Licensee MDPI, Basel, Switzerland. This article is an open access article distributed under the terms and conditions of the Creative Commons Attribution (CC BY) license (https:// creativecommons.org/licenses/by/ $4.0 /)$.

\begin{abstract}
Society recognizes the need to progress towards equal opportunities for leadership at all levels of political and economic decision-making for women and requires that companies work to reach that goal. Nevertheless, leadership education should begin in the educational stages. This research presents a collaborative model of leadership education for high-potential female undergraduate students carried out at the university level between 2017 and 2020, with 75 students. To be successful at improving student leadership skills, self-esteem, self-confidence, and personal inner transformation, this women's leadership development program was based on four lines of innovation: (a) attracting external stakeholders to develop training jointly; (b) making an open program with multidisciplinary students in social sciences and STEM subjects tailored to the professional environment; (c) measuring the learning with all the participants: trainers, directors, managers, program staff and students, using a 360-degree evaluation; and (d) designing an ongoing research process to incorporate improvements from multiple stakeholder perspectives. A multi-source program assessment was used. The results not only show a positive impact on the students' acquisition of leadership skills but also, on the increase in self-confidence and ambition. The study provides a pioneering model for women's leadership education that could be used in other similar programs.
\end{abstract}

Keywords: open innovation; leadership skills training; self-confidence; female learning; female barriers

\section{Introduction}

Encouraging women leaders is important to reduce the huge gap in female representation in executive positions. A Catalyst 2020 census of Fortune 500 companies in the USA in 2020 (Dow Jones Indices) found that women held only $5.8 \%$ of CEO positions and only $21.2 \%$ of corporate board seats in S\&P 500 companies [1]. In addition, the COVID-19 crisis might exacerbate these gender inequalities in the labor market [2], which are referred to as the "Glass Ceiling". This is also reflected in the managerial positions occupied by women, at just $34 \% ; 24 \%$ of parliamentarians; and $18 \%$ of government ministers [3]. The literature (human capital theories) indicates lack of self-confidence and lack of specific training [4-6] as two of the barriers to women's access to leadership positions. University education is highly relevant in training the future leaders of society and therefore higher education is an ideal place to produce personal change in women students, enhance their self-esteem and self-perception and make them feel that they can become leaders. For this reason, European higher education has made social dimension challenges a priority [7]. Issues such as progress in women's leadership and gender equality with equal opportunities for leadership at all levels of political and economic decision-making for women are becoming more relevant. It is recognized that the gender imbalance, if it has been improving somewhat, is still marked in some areas $[7,8]$.

The aim of this article is to present a Women Leadership Development Program (WLDP), with the participation of 75 female university students, and the principal findings after three one-year courses carried out between 2017 and 2020. The program was born 
on the basis as Debebe et al. [9] (p. 233) point out "leadership development programs have the potential of fostering transformational change by creating learner awareness of problematic habitual patterns and providing a safe space for envisioning and practicing alternative patterns".

The first question posed by the implementation of the WLDP was: what content and training should it have? One popularized term referring to the knowledge flow and collaboration across organizational borders is 'open innovation' (OI) [10]. Collaborative innovation entails collaboration across areas of expertise, which not only combines domain specific expertise but also gives rise to joint practices that are needed for the integration of highly varied contributions [11]. Furthermore, as stated by Day and Dragoni [12], developing effective leaders requires an understanding of the precursors, practices, and outcomes of successful leader development and should be accompanied by a corpus of research evidence and suitable theoretical foundations. In this perspective, the WLDP was designed jointly by academics and external stakeholders, managers, and leaders of companies and other bodies, exemplifying the organization of collaborative innovation.

The literature related to OI and universities is prolific and varied. Studies have focused on topics such as collaboration, R\&D, networks, knowledge-transfer, and universityindustry [13-16]. However, the educational environment is an area where a great deal of further development is still needed. Implementing an OI paradigm that involves students, lecturers, managers, and leaders, can improve motivation and learning, and therefore the professional outcome [17]. Therefore, the complexity thinking represents a key perspective for a deeper understanding of innovation and the patterns of interactions between stakeholders that enable the emergence of novelty $[18,19]$.

In recent years, there has been a trend towards research into entrepreneurship, such as the research of Karlsson and Warda [20] testing whether the benefits associated with OI are transferable to entrepreneurship and innovation networks, and education management [13]. Likewise, the OI approach is used for entrepreneurial education, focusing on cooperation between industry and universities to prepare students for corporate entrepreneurial thinking [21], by identifying the most effective teaching methods to enhance the main stakeholders' motivation and improve higher education training in entrepreneurial competences of employability [22,23]. Beckman et al. [24] highlight collaborative innovation through an integrated interdisciplinary course that interweaves personal development and growth with problem solving skills, and diverse-team participation and leadership.

Regarding the WLDP, previous research describes the collaboration between universities and different internal stakeholders and external leaders [25-28]. Nevertheless, some studies have noted that the majority of leadership development programs currently being designed and implemented are not effective [29]. According to Ely et al. [30] women's leadership training is criticized for creating artificial environments which are not congruent with the mixed teams that women must lead. Other positive perspectives of analysis point out that WLDPs invite women to share the professional experiences that otherwise, would not be shared for fear of being rejected in mixed programs [31]. Madsen and Andrade [29] highlight that the design, development, and content of effective women-only programs, must be based on two points: current leadership research and theory [32]; and the background and experience of stakeholders with experience in leadership, gender, adult learning, and organizational change [33]. Therefore, a holistic methodology with an Open Innovation approach in the design, contents, methodology, training, and evaluation of the WLDP is needed.

WLDP in universities have proven their successful application for many audiences, including lecturers, university staff, and communities. WLDPs in higher education have focused on developing leadership skills that contribute to career positioning in the administrative staff and contribute to climbing the ranks for female lecturers [34-41]. To a lesser extent, research has focused on students [25-28,42,43], and when programs for undergraduates students have been investigated, these have been mixed-gender programs [25-28,44]. However, research into the results of WLDPs exclusively for female undergraduate stu- 
dents is scarce. In the case of Ericksen [42], the investigation was focused on students with a variety of profiles (science, education, engineering, arts, health sciences) and different racial groups. The results support a positive impact on career transition decision-making, leadership skills, assertiveness, and empowering women.

However, this study does not carry out a detailed analysis of the structure of the program. Brue and Brue [43] focuses on the post-training analysis of the course, presenting a qualitative longitudinal research (course cohorts) of technology profiles. The research shows that the WDLP contributed to relevant changes in the students, such as increased selfconfidence, adoption of strategic thinking and communication skills. In later work, Brue and Brue [45] also draws attention to the program's contribution to building leadership and self-identity. However, this research does not detail the structure of the course or the methodologies used for program evaluation.

On the other hand, from the perspective of WDLPs, these programs focused on measuring the effectiveness of the course through acquired leadership skills, knowledge and satisfaction [35,38,39], and affective reactions [46]. Nevertheless, less attention has been paid to aspects such effective monitoring of the classroom environment (the emotions of students and trainers) [43,47]. Also, these programs aimed at undergraduate female students do not evaluate the program itself, from an implementation point of view, nor the relationship between the stakeholders, trainers, and students as elements that influence the program.

Therefore, the second question arises: How should the WLDP's effectiveness be measured? In this sense, the degree of training obtained by the participants, the emotional classroom environment and the relationships with stakeholders must be considered. The evaluation system should also detect deficiencies and identify points for improvement with an open innovation approach.

Based on the above, in this work, we present a program for undergraduate female leadership training, with the intention of responding to the two main questions posed, applying a model with an OI focus. Furthermore, compared to previous research the innovative model of leadership learning includes a 360-degree evaluation where trainers, directors, managers, program staff, and students participate, and where emotions have been considered. In summary, it should be emphasized that this research work overcomes the two main gaps referred to about prior knowledge: research not focused on undergraduate students and the application of a holistic open innovation approach and evaluation.

The paper is structured as follows: Section 2 explains the methods, sample and analytical procedure; Section 3 describes the conceptual WLDP model, background, evolution, innovation, and improvements; Section 4 outlines the main results; and Section 5 presents the discussion and main conclusions.

\section{Methods, Sample, and Analytical Procedure}

The study presents exploratory research through an in-depth case analysis $[48,49]$ analyzing a Women Leadership Development Program (WLDP) an innovative model for leadership learning and an evaluation of the results. This approach (case study) provides a detailed description and analysis to gain a better understanding of the patterns, relationships and results [50].

Evaluating leadership programs holistically would enable more accurate research involving the effect of training design, and delivery and implementation characteristics [46].

As a means to frame the focus of evaluation, on the basis of complexity theory, the study design articulates mixed methods to capture this complexity [51].

Hence, our approach to the leadership program assessment included a comprehensive holistic methodology $[30,52,53]$ using qualitative and quantitative techniques. It facilitated the comparability of data obtained by different methods allowing cross-validation when the results were similar in both. In addition, we included two informants: the students and the trainers. Furthermore, the researchers conducting the fieldwork did not interact with 
the students to maintain their independence from students and trainers, thus favoring the spontaneity of the responses and the reduction of bias.

\subsection{Indicators, Instruments, and Sample}

For the program assessment, three indicators were defined according to the three different informants. Data collection on the first indicator is based on students as informants; the second indicator on trainers and the third one, on staff as research informants.

\subsubsection{Indicator $1-$ Students as Informants}

The study design for an in-depth WLDP evaluation analysis of students used a sequential explanatory design [54] consisting of two phases: quantitative data from an online survey (Phase 1) and then qualitative focus groups (Phase 2). Thus, the data from the qualitative focus groups helped explain the quantitative results and provided explanations for the same themes and other issues. Both results were connected for better understanding of the findings from both phases. The same exploratory design was applied to the three editions of the WLDP.

This multi-methods evaluation design (Phase 1 and Phase 2) helped to improve the WLDP evaluation system. The qualitative results (Phase 2) of the WLDP first and second edition and the informal interviews with participants revealed that emotions have a key role in their training and personal transformation. Therefore, in the third edition, the survey questionnaire (Phase 1) was extended, including a new block for the measurement of emotions. This decision was justified according to the literature reviewed. Research on the influence of emotions in the learning process has shown that they are relevant to promoting a student's personal change, leading to an approach that lasts in time [55]. Specifically, studies in leadership training programs demonstrate that emotions influence the perception and insight of the trainees as leaders [56]. Negative emotions like stress are associated with increased critical thinking, which leads to a realization of current skills and how to develop future ones [57]. In addition, positive emotions are associated with higher levels of learning in leadership training [58]; foster more autonomy and participation in the academic environment, as well as being positively associated with learning goals and to a lesser extent with work avoidance [55].

Phase 1 Quantitative Methodology_Assessment of Formal Training and Emotions

The objective of this quantitative phase was to investigate the perception of the performance of the WLDP itself and the training received (leadership competences), the detection of key moments in the training (practice and theory), errors in the transfer of knowledge and the monitoring of learning methodologies to remedy possible problems encountered $[30,46]$. For this purpose, a quantitative survey was developed at the end of each theoretical module using a self-administered online survey.

Sample

The survey sample was 75 students, 25 in each course of the three editions of the WLDP, none of whom declined to answer the questionnaire. On average, they were 21.6 years old and were in the last year of their Bachelor's degree in Business, Economics, Philosophy and Political Science, International Relations, Public Relations and Advertising, Journalism, Law, Engineering, Architecture and Design, and Fine Art. Some of them were combining their university classes with their mandatory business practices.

\section{Instrument}

The instrument was based on the [59] previous, validated scale. The questionnaire was designed with a 10-point Likert scale with nine questions about the theoretical and practical subjects, the course materials, and the trainers, in addition to their previous knowledge about the topics, how the module contributed to their future and capability, and a global evaluation. Internal consistency was validated as a research instrument 
by applying Cronbach's alpha for all the questions, obtaining reliable values $(\alpha=0.87)$. Also, the questionnaire included an open space at the end where students could include comments about the WLDP and express themselves. Most of them added some positive comments at the end of the questionnaire. This block of questions in the instrument was the same in the three editions of the WLDP.

As a novelty, in the third edition of the program, the instrument added a new block with questions about the students' emotions. Following the objective to properly evaluate the relationship between emotions, the learning process and personal inner transformation, the Achievement Emotions Questionnaire (AEQ) scale was applied [60]. This scale "is designed to assess various achievement emotions experienced by students in academic settings" [60] (p. 1). The instrument contains 24 items measuring enjoyment, hope, pride, relief, anger, anxiety, shame, hopelessness, and boredom during class. It has three scales consisting of eight items each: class-related emotions, learning-related emotions, and test emotions. From these, we chose all the test emotions (8), two more items from class-related emotions (1) and learning-related emotions (1). This scale was reviewed by two authors with expertise in women in leadership positions, who rewrote and reviewed the items which were difficult to understand due to translation to Spanish and added three more items. Altogether, the emotions scale demonstrated an acceptable internal consistency reliability $(\alpha=0.72)$. Participants rated all the items on a 10-point scale from 1 (never) to 10 (always).

Phase 2 Qualitative Methodology: Students' Perception of Their Inner Personal Transformation

The qualitative phase sought a deep comprehension of the individual's inner transformation by evaluating the impact of the WLDP on improving self-confidence, students' self-perceptions, and leadership motivations. Nevertheless, the explicit aim was to evaluate the students' perceptions of the program and the lessons they learned from it.

A total of six focus groups were carried out in the WLDP's three editions and a total of 32 students were involved in this evaluation: two focus groups per year and between six to eight participants in each one. Participation was voluntary, but most students were eager to take part. The focus groups were held at the end of the course, although not immediately, but two weeks after, in order to allow time for reflection by the participants [20,32]. Each focus group lasted more or less one and a half hours and used open questions. A script, proposed to unify the interview criteria, was used exclusively to guide the focus group, but in all cases, it was decided to leave the participants enough flexibility to develop their own opinions. The script included themes related to the assessment of the training but also, a special theme about emotions and students' perceptions about inner transformation. All the focus groups were transcribed with the participants' consent.

\subsubsection{Indicator 3: Trainers' Perceptions}

The need to include all the stakeholders as evaluators [9,47], in addition to addressing a less endogenous evaluation [46] in this WLDP, led to another methodological change in the third edition. In-depth interviews with trainers (managers) were included, which were analyzed qualitatively.

The objective of this new change was to expand the information on the trainers' perceptions of the students and the program. Specifically, six aspects were considered based on a script: perception of students' emotions, moments of engagement (classes), classroom environment, students' leadership skills, perceptions of their own emotions, and insights about their work. They were conducted with seven trainers who gave the researchers their consent for data analysis (results are shown in Section 4). The interviews lasted between 30 and $50 \mathrm{~min}$. This indicator made it possible to compare the information obtained from the students about their training. The interviews were transcribed, and a conventional content analysis (inductive analysis) approach was applied [61]. 


\subsubsection{Indicator 4: Staff Perception and Assessment}

Joint observation within the classroom environment by a researcher and a WCA manager, thus involving another stakeholder in the evaluation of the WLDP, was also used as a research methodology in all three years of the course. The researcher, presented as a spectator, did not participate, but noted the events that took place in the class. In the evaluation, the notes of both were gathered to qualitatively analyze the course and training development.

Moreover, in order to align the WLDP objectives with those of the stakeholders [47] and to follow up in close coordination, a formal, informal, and continuous communication process was established (before starting the course, during the classes, and after the training) through meetings, emails, and phone calls.

\subsection{Analytical Procedure}

The quantitative data were analyzed using SPSS25. First, univariate analyses were conducted through frequency analyses, mean values, and standard deviation to examine the opinions about the WLDP, the training received and the emotions that they felt during the course.

Second, bivariate analyses were conducted using an analysis of variance (ANOVA) with a Kruskal-Wallis test to identify inter-group differences by the year of course attendance, we used a post hoc Bonferroni test accepting $p$-values below 0.05 as significant in both tests.

The qualitative analysis. Both the student focus groups and the trainers' interviews were recorded with the participants' consent and transcribed later. A conventional content analysis (inductive analysis) approach was applied in order to capture relevant information [61]. The analysis progressed following the classical steps of familiarization, data reduction, pattern identification, re-construction, and generalization [62]. No software was used for this analysis.

\section{Women's Leadership Development Program: Background and Innovations}

\subsection{Attracting External Stakeholders to Jointly Develop Training}

Promoting female leadership in the academic context requires external stakeholders, managers, and leaders of companies and other organizations, to develop training jointly. They are a key element in identifying the shortcomings of female graduates when they enter the labor market and in training them in leadership skills using different methodologies [9]. In short, they are fundamental for the transfer of experience and knowledge to female students from business practice $[9,47]$. Therefore, the trainers, both male and female, were experienced and committed managers from different economic sectors. The program was launched by Universidad Rey Juan Carlos (URJC) in collaboration with an association of women entrepreneurs and managers, the Women CEO Association (WCA), whose objective is to promote women to managerial positions and boards of directors, insisting on parity and diversity. With this pioneering initiative of high social value, the WCA seeks to position itself as an innovative institution. URJC sought to network with companies and organizations to bring practical value to undergraduate studies. The joint initiative arose in part as a consequence of the shared concern between both institutions about the growing setback that was noticed among young women in matters of gender equality.

The first course was sponsored by the WCA. The Fundación Banco de Sabadell was the sponsor of the second one, in 2018, and incorporated some additional activities to the program explained at the end of this Section 2.1. The sponsor of the third course was the Fundación Obra Social La Caixa, of the Caixabank group, first Spanish bank in activity ranking, also incorporated Design For Change [63] as an academic partner. The collaboration of the sponsors went beyond financing and is a consequence of their concern for social issues such as youth, leadership, and gender equality. They were involved in the design, providing teachers and mentors. The program also served the companies and organizations that participated in attracting talent. 
The leadership is recognized as an ability that increases one's worth in an international labor market [3] and student leadership is becoming an increasingly stated priority for universities [64]. Leadership is one of the so-called transversal competencies or soft skills, to which special relevance has been given; these abilities are defined as intangible personal talents which are essential in the workplace as these skills cut across jobs and sectors [65-69]. A good leader must be able to communicate, coordinate, reach agreements, motivate and work in a team, in an increasingly changing and globalized environment [70]. Therefore, the modules were designed according to these needs, seeking the development of competencies and skills from different areas. The WLDP methodology is an active one with workshops, action-oriented dynamics [71] and the intervention of managers who act as guides. The sessions always started with a first part, as short as possible, of theoretical introduction followed by a practical development of the modules. The first course had eight modules, each lasting $4 \mathrm{~h}-\mathrm{a}$ whole afternoon, always on the same day of the week to optimize the planning of the students' time, allowing them to make their workload compatible with their undergraduate studies.

A professional mentoring program is included. The WLDP is not part of the official curriculum as it is not in the curriculum of any particular course, but it is considered in the final grade through a subject called Academic Recognition of Credits that is designed to encourage the integral formation of students through their participation in various types of activities (social, cultural, and sports) that students are free to take. Is it elective for every student in the university, regardless of the area of study.

The working teams were multidisciplinary and were formed by five people to elaborate a case study. The WCA supported the groups during the process and the papers were presented in the last session to a mixed panel of managers and academics [72]. The evaluations of each course led to changes that are explained in Section 3.3.1 The topics in the first course are shown in Table 1.

Table 1. Content of the first course.

\begin{tabular}{|c|c|}
\hline Subject & Subject Objective \\
\hline $\begin{array}{l}\text { Personal branding, social media } \\
\text { and networking }\end{array}$ & $\begin{array}{l}\text { From leisure networking to quality professional networking. } \\
\text { The importance of the digital footprint in personal branding } \\
\text { and social media. }\end{array}$ \\
\hline Communicating efficiently & $\begin{array}{l}\text { Public communication techniques through storytelling to } \\
\text { catch attention and influence. }\end{array}$ \\
\hline Oral and public speaking & $\begin{array}{l}\text { Oral presentation training in the lecture hall using performing } \\
\text { arts techniques with professional actors. }\end{array}$ \\
\hline Leadership style and techniques & $\begin{array}{l}\text { Female and male thinking. Identification and integration of } \\
\text { styles and techniques appropriate to their professional career, } \\
\text { seeking motivation for team management. }\end{array}$ \\
\hline Negotiating Efficiently & $\begin{array}{l}\text { Goal-oriented to improve negotiation skills in collaborative } \\
\text { contexts integrating cultural diversity (this learning is not } \\
\text { common in formal studies). }\end{array}$ \\
\hline $\begin{array}{l}\text { Protocol and } \\
\text { Business management }\end{array}$ & $\begin{array}{l}\text { Management through company values to guide the creation } \\
\text { of social value from the perspective of a globalized, digital, } \\
\text { collaborative economy. }\end{array}$ \\
\hline The transforming woman & $\begin{array}{l}\text { Managing the future from private and professional life to } \\
\text { professional career using a transformative vision, managing } \\
\text { the different roles that students will have throughout their } \\
\text { lives to achieve professional and personal balance. }\end{array}$ \\
\hline Case Study: WCA Junior & $\begin{array}{l}\text { Presentation of the final session to propose the creation of } \\
\text { WCA Junior with the objective of establishing a stable link } \\
\text { and networking between the participants and WCA members. }\end{array}$ \\
\hline
\end{tabular}


The program has a mentoring system that was changed. In the first course, there was one mentor for each work team, which was changed to a single mentor for the 25 students in the second course. However, the collective mentor was one of the aspects with the worst evaluation of the participants; therefore, it was changed in the 2020 course and returned to the initial system, but instead of doing it in groups, it was with one-to-one mentors, professionals that carry out their activity in sectors according to the profiles of the students.

In the different courses, we also carried out some activities outside the program, taking advantage of opportunities that arose. In the first course, a visit was made to the Equality Commission of the European Parliament (Brussels), which was very well received by the students. In the second course, two activities promoted by the sponsor were incorporated: (1) a scholarship for a month's stay in Silicon Valley in the Imagine Silicon Valley program to attract talent and promote entrepreneurship and intrapreneurship [73], this opportunity was interesting because it generated competitiveness among the participants; (2) two group coaching sessions, of great interest but which the students saw as an extra workload. Lastly, students were given an individualized test on their own leadership style and competencies, thanks to the collaboration of a Coaching Human Resources Company, Psicotec.

\subsection{Open Program with High Potential Multidisciplinary Students}

From the beginning, talent was sought, enrolling women undergraduates with high potential to empower these young females [59]. The selection process had an innovative approach, with a mixed selection committee between WCA and URJC academics to avoid bias towards a more professional or more academic talent profile. This shared selection process became one of the strengths of the program and part of the training. The applications for enrolment in the WLDP were three times the number of places offered. The selection had two phases: an online questionnaire (first filter) and a personal interview structured according to the BEI methodology (behavioral event interview) [74] recommended by the WCA's human resources managers.

Four areas were addressed: socio-economic and cultural context, personal vocation, personal leadership, attitudes, qualities, interests and social awareness, openness to the world and its challenges, with the aim of forming women leaders committed to Sustainable Development Goals [75].

The final groups constituted a heterogeneous team in terms of their academic profiles, including students pursuing Bachelor's degrees in Business, Economics, Philosophy and Political Science, International Relations, Advertising and Public Relations, Journalism and Audiovisual Communication, Law, Engineering, Architecture and Design, and Fine Art. Some of them were combining their university studies with their mandatory business practices. It was intended that the program provided access to leadership training not only to students in Business, but also to those with more technical profiles, especially STEM subjects. This multidisciplinary group will lead them to create broader and richer networks in the future [76].

\subsection{An Ongoing Research Process to Improve the WLDP \\ 3.3.1. Training Improvement}

The module on women transformers was eliminated in the second edition, as it was not well valued. However, it was considered fundamental and very relevant to the program. Its objective was to offer a vision of gender equality, highlighting the importance of coresponsibility in the family when women access positions of responsibility [77]. This dual vision was incorporated into the following courses in a transversal manner in all modules, with more participatory methodologies, seeking a reflection exercise for young women and with the participation of female managers from large companies.

In the evaluations of the first course, it also became clear that it was important for the students to understand the objectives of the program, to generate group dynamics from the beginning and a sense of belonging. For this reason, it was decided to start with a module called "Social and Business Context: Bringing Women Role Models to the Classroom". The 
case study on the realization of a WCA Junior creation project was also not well appreciated. Therefore, it was oriented to the search for solutions to real problems related to the SDGs and Agenda 2030. In this way, the selected candidates' concern for social issues continued to be emphasized. Finally, there was a simple name change: the Protocol and Business Management module was renamed "Business Management".

However, in the research carried out at the end of the second course "Business Management" was one of the lowest rated modules, its contents were perceived as being closer to more theoretical academic subjects or business knowledge, for this reason it contributed less value than practical topics. It was also eliminated in the third course, including new content and activities. The other important change was to replace the case study with a hackathon. The duration, contents of the program and the unequal previous knowledge of the students meant that the case study was not being carried out correctly, and it also caused a high level of stress, as shown by the students in the Focus Groups. The hackathon was considered suitable for the objectives of the program as it is a methodology that involves the students in the active search for solutions to specific challenges, in the WLDP it was the achievement of equality between men and women through a short activity. However, the COVID-19 pandemic meant that the last two modules took place in September instead of March as planned and had to be online. A hackathon is very intensive in terms of the process and results, thus it was thought that it would be very difficult online, so that methodology was changed to design for change (DFC), derived from design thinking that teaches how to identify and address complex problems [78] skills that are increasingly in demand [3]. During this last module students developed "empathy, creativity, teamwork, critical thinking, and shared leadership" [63].

Table 2 shows the evolution of the contents of the program up to its third edition. The training incorporated the improvements mentioned above, attempting to integrate the three modes of attention that the leader manages in their teams "inners, others, outers" [24,79]. Specifically, the first module incorporated a meeting with the CEO of a multinational so that they could learn about the context in which they would develop their professional activity, but without forgetting the social context (outers) and a very necessary aspect, the professional and personal experience of the leading speaker, as a reference (inners, outers), an often repeated requirement in the focus groups. The theoretical contents that would also be incorporated in an applied form in this first module were reduced. In addition, the module personal profile analysis was introduced, which involved a self-exploration of the students, in order to become aware of their life, to make an analysis of their strengths and weaknesses and to provoke a rethinking of their professional careers in this new personal context. This was necessary to make the most of the following personal branding module. The word networking with a specific section formally disappeared from the program but, aware of the importance of learning to weave their networks, it was incorporated transversally throughout the WLDP $[79,80]$.

\subsubsection{Improvement in the WLDP Evaluation System}

In the third edition, there were two methodological changes. The first, a quantitative analysis of the students' emotions from the items added in the final survey (module). The second, qualitative analysis based on in-depth interviews with trainers that adds a new actor (stakeholder) to the program evaluation system. 
Table 2. Training improvement.

\begin{tabular}{|c|c|c|}
\hline First Edition & Second Edition & Third Edition \\
\hline $\begin{array}{l}\text { Personal branding, social } \\
\text { media and networking }\end{array}$ & $\begin{array}{l}\text { Social and business context: } \\
\text { Bringing women role models } \\
\text { to the class } \mathbf{N}\end{array}$ & $\begin{array}{l}\text { Social and business context: } \\
\text { Bringing women role models } \\
\text { to the class }\end{array}$ \\
\hline Communicating efficiently & $\begin{array}{l}\text { Personal branding, social } \\
\text { media and networking }\end{array}$ & Personal profile analysis $\mathbf{N}$ \\
\hline Oral and public speaking & Communicating efficiently & $\begin{array}{l}\text { Personal branding and } \\
\text { social media }\end{array}$ \\
\hline $\begin{array}{l}\text { Leadership style } \\
\text { and techniques }\end{array}$ & Oral and public speaking & Communicating efficiently \\
\hline Negotiating Efficiently & $\begin{array}{l}\text { Leadership style } \\
\text { and techniques }\end{array}$ & Oral and public speaking \\
\hline $\begin{array}{c}\text { Protocol and } \\
\text { Business management } \mathrm{C}\end{array}$ & Negotiating Efficiently & $\begin{array}{l}\text { Leadership style } \\
\text { and techniques }\end{array}$ \\
\hline The transforming woman $\mathrm{C}$ & Business management $\mathbf{R}$ & Negotiating Efficiently \\
\hline Case Study: WCA Junior ${ }^{C}$ & $\begin{array}{c}\text { Case Study: ODS } \\
\text { Agenda } 2030^{\mathbf{R}}\end{array}$ & Design for Change (DFC) $\mathbf{N}$ \\
\hline
\end{tabular}

${ }^{\mathrm{C}_{\text {Change, }}}{ }^{\mathbf{N}} \mathrm{New},{ }^{\mathbf{R}}$ Removed; Source: The authors.

\subsection{Conceptual Model}

In summary, the conceptual model of leadership learning for female university students shown in this paper is based on four innovation perspectives: (a) attracting external stakeholders to jointly develop training (content and methodology) to improve student leadership skills, self-esteem, self-confidence, and personal inner transformation; (b) making an open program with multidisciplinary students in social sciences and STEM subjects adjusted to current needs in the business environment but complementary to the formal degree curriculum; (c) measuring the degree of training of the participants with a 360-degree evaluation where trainers, directors, managers, program staff, and students participate; and (d) designing an ongoing research process to incorporate improvements from multiple stakeholder perspectives. A multi-source program assessment was used. Following a triangulation methodology, online surveys and focus groups with students, as well as in-depth interviews with lectures and staff were carried out. Figure 1 shows the conceptual model.

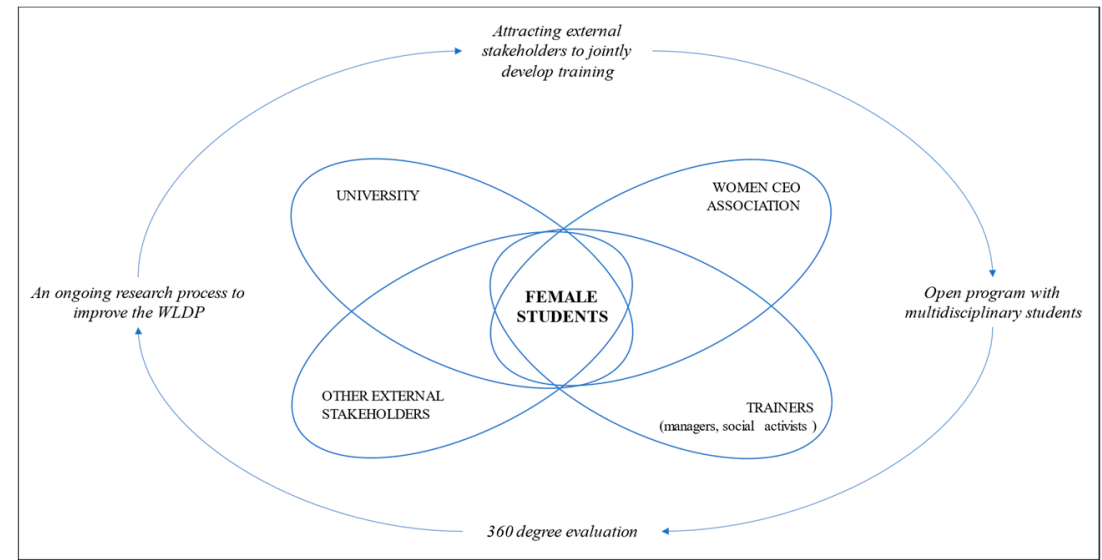

Figure 1. Women's Leadership Development Program with an Open Innovation Approach.

\section{Results}

The results presented in this section show the main outcomes of the quantitative program evaluation indicators for the three years. Therefore, they are focused on Indicator 1 (Students as Informants) due to the fact that it was used in all three editions. Nevertheless, 
the results include some input from trainers (Indicator 3) and staff (Indicator 4) to explain some outcomes, even when these two informants were only included in the third edition of the program.

\subsection{Assessment of the WLDP Program and the Training Received}

Indicator 1 measures the students' opinion: the training, the learning and the global evaluation. As Table 3 shows $(\mathrm{M}=8.82 ; \mathrm{ST}=1.25)$, the evaluation of the course as a whole was excellent and an improvement can be seen year by year. This indicates that the continuous improvements in the program favored an adjustment in the quality of the training, as was already evident. The students most valued the possibility of presenting their concerns to a professional during the classes, highlighting the benefits of mentors managers to students; and, also, the fact that the program stimulated their desire to know more and the applicability of the knowledge acquired for the future.

Table 3. Descriptive results of training, learning and global evaluation for all three years and a comparison of the results year by year (on average). Scale from 1 = Very Bad; 10 = Very Good and results of ANOVA analysis by year.

\begin{tabular}{|c|c|c|c|c|c|c|c|}
\hline \multirow{2}{*}{$\begin{array}{l}\text { Class Training } \\
\text { Evaluation }\end{array}$} & & \multirow{2}{*}{$\begin{array}{l}\text { Three-Years } \\
\text { Mean }\end{array}$} & \multicolumn{4}{|c|}{ ANOVA by Group } & \multirow{2}{*}{$\begin{array}{c}\text { Kruskal-Wallis } \\
\text { Test }\end{array}$} \\
\hline & & & ST & 2017 Mean & 2018 Mean & 2020 Mean & \\
\hline \multirow{4}{*}{$\begin{array}{l}\text { Theoretical } \\
\text { subject matter }\end{array}$} & Theoretical subject matter & 8.7 & 1.44 & 8.7 & 8.7 & 8.7 & \\
\hline & Practical subject matter & 8.9 & 1.36 & 8.6 & 9.0 & 8.9 & $0.009^{* *}$ \\
\hline & $\begin{array}{l}\text { Provide answers to the } \\
\text { queries made }\end{array}$ & 8.9 & 1.28 & 8.7 & 9.2 & 8.9 & $0.014^{* *}$ \\
\hline & Course materials & 8.5 & 1.80 & 7.9 & 8.9 & 8.5 & $0.001^{* * *}$ \\
\hline \multirow{3}{*}{ Learning } & $\begin{array}{c}\text { Previous knowledge of } \\
\text { the subject }\end{array}$ & 6.0 & 1.77 & 6.3 & 5.6 & 6.2 & \\
\hline & $\begin{array}{l}\text { Provided applicable tools } \\
\text { for the future }\end{array}$ & 8.8 & 1.31 & 8.7 & 8.8 & 8.8 & \\
\hline & $\begin{array}{l}\text { Motivated to want to } \\
\text { know more }\end{array}$ & 9 & 1.34 & 9 & 8.9 & 9.1 & \\
\hline Global evaluation & & 8.8 & 1.25 & 8.7 & 8.8 & 9 & \\
\hline
\end{tabular}

The descriptive analysis by year shows that the mean values obtained in all the items over the years, especially highlight an improvement in the values for the second year with respect to the first year. However, to validate the robustness of these descriptive analyses, a stochastic analysis was performed using an analysis of variance and a post hoc test to determine the inter-group differences. Despite the differences in the means over the years in terms of training received or learning, these were only statistically significant $(\mathrm{H}(2)=13,430, p<0.001)$ in the case of "Course materials"; "Practical Subject matter", and "Provide answers to the queries made". In the Kruskal-Wallis Bonferroni Post Hoc test, the two-by-two comparisons showed that both "Course materials" and "Provide answers to the queries made" are only significant in the comparison between the first year and the second year $(p<0.05)$. As far as "Practical Subject matter" is concerned, there were differences between the first year and the next two editions, which suggests that the practical classes also improved over the years $(p<0.05)$. There were no significant differences between the second edition of the program and the last one, implying that the greatest change occurred between the first two editions. In summary, it seems that opinions increased from the first year to the following editions (the second and the third), which showed little change.

One of the main program objectives was to provide students with abilities and skills in leadership for the future. Regarding this goal, there is a statistical relationship $(\mathrm{H}(2)=114,540, p<0.000)$ between all the training items (theoretical and practical matters, provide answers to queries, course materials) and the affirmative opinion about the fact that this goal was achieved. Table 4 shows that the possibility of expressing queries, interacting with professionals and the focus on practical matters obtained the highest means. 
Nevertheless, the comparison of each pair using a Kruskal-Wallis Bonferroni Post Hoc test, showed that in all these training items, the greatest differences were always between the group of those that strongly agree considering that the program facilitated skills for the future ("too much"-> "not too much", $p<0.000$; "too much"->"adequate", $p<0.000$ ) with those who were less confident about the applicability of these skills for future careers ("not too much"->"adequate").

Table 4. Results of ANOVA analysis by group. Kruskal-Wallis Bonferroni Post Hoc.

\begin{tabular}{cccccc}
\hline & $\begin{array}{c}\text { Provided Applicable } \\
\text { Tools for the Future }\end{array}$ & Mean & ST & Minimum & Maximum \\
\hline \multirow{3}{*}{ Theoretical subject matter } & Not too much & 6.6 & 1.58 & 4 & 10 \\
& Adequate & 7.8 & 1.34 & 4 & 10 \\
& Too much & 9.3 & 1.03 & 5 & 10 \\
\hline \multirow{3}{*}{$\begin{array}{c}\text { Practical subject matter } \\
\text { Not too much }\end{array}$} & Adequate & 6.8 & 1.59 & 5 & 10 \\
& Too much & 9.3 & 1.37 & 3 & 10 \\
\hline Provide answers to the & Not too much & 6.9 & 1.73 & 3 & 10 \\
\hline queries made & & & & & \multirow{2}{*}{3} \\
\hline
\end{tabular}

Elaborating on the assessment of the training activities, Table 5 shows the evaluation of those modules that remained over the years. Analyzing the results of the students' evaluation per module, overall, all of them indicated very high evaluations and none of them below 8.3 (the measurement scale is from 1 to 10). The module "Public Speaking" along with "Social Media and Networking" and "Personal Branding" were the three modules that obtained the best scores year after year, considering that the relationship between opinions of the modules and year was statistically significant $(\mathrm{H}(5)=20,024, p<0.001)$. "Negotiating Efficiently" was the worst evaluated in the first year, but it performed very positively over the next years (from 7.8 to 9.1). "Leadership Style" had a slight drop in the last year, from 8.8 to 8.6. Due to COVID-19 during 2020, it had to be taught online after the national lockdown, changing the root of the module's methodology. It is noteworthy that, despite the change, all the students connected to the online sessions, and the assessment did not drop too much. In summary, these results show the adequacy of changes in content and training strategies improving year by year, which favored an increase in their assessment.

Table 5. Descriptive results of The Global Evaluation of the Remained Modules (on average). Scale from 1 = Very Bad; 10 = Very Good.

\begin{tabular}{cccccc}
\hline \multirow{2}{*}{$\begin{array}{c}\text { Subject-Module } \\
\text { Global Evaluation }\end{array}$} & \multicolumn{4}{c}{$\begin{array}{c}\text { Thesults of ANOVA } \\
\text { Analysis by Module and Year }\end{array}$} \\
\cline { 2 - 6 } & Mean & ST & 2017 Mean & 2018 Mean & 2020 Mean \\
\hline Public Speaking & 9.3 & 1.08 & 8.7 & 9.5 & 9.3 \\
Social Media and & 9.0 & 1.05 & 8.8 & 9.0 & 9.1 \\
$\quad \begin{array}{c}\text { Networking } \\
\text { Leadership styles }\end{array}$ & & & & & \\
and techniques & 8.7 & 1.30 & 8.8 & 8.8 & 8.6 \\
Negotiating Efficiently & 8.3 & 1.46 & 7.8 & 8.1 & 9.1 \\
$\quad \begin{array}{c}\text { Personal Branding } \\
\text { Communicating efficiently }\end{array}$ & 8.9 & 1.21 & 8.7 & 9.1 & 8.9 \\
\hline
\end{tabular}

Further evidence of this came from the focus groups. One of the most outstanding issues, according to their opinions, was learning to evaluate themselves, looking inside themselves to identify their professional strengths and weaknesses, and the different aspects to which they should pay attention to mark their own path was something that they repeatedly emphasized. As they expressly said, "This program goes beyond academia" 
(Focus Group 2, first year), they felt that it had changed their lives and they verbalized this. For example, students repeatedly highlighted that learning to listen was an important part of communication, negotiation and leadership. One of the trainers mentioned the following in their interview: "A key moment of the session was realizing that they don't know how to listen and it is difficult to communicate with other people and even more difficult to influence, if you don't know how to listen".

In the Social Media and Networking module, a change began to take place in the students. For formal purposes, they learned and discovered the importance of their image in social networks and how to project themselves in the professional field. However, given the variety of profiles, mutual help between peers was generated, creating a network that consolidated the feeling of belonging to the group, where each one contributed with their knowledge, passions and emotions. This was thanks to two very careful aspects of the organization: on the one hand, the selection process that configured a very diverse group both from the point of view of curricular knowledge and particular tastes and interests and, on the other hand, the dynamics of the sessions, the orientation, and even the layout of the room.

This group cohesion was strengthened in the Public Speaking module each year, where they all experienced some insecurity but felt protected by the group. In Focus Group 6 (third year) they related the importance of learning to see the difference between how you feel when facing communication in public, usually insecure, and the perception that the audience has of you "without being judged". For this reason, it was one of the modules that were decisive, in terms of knowledge and feelings-emotion. For formal educational purposes, the module taught verbal and body language, relaxation techniques and guidelines for projecting their image and voice. Thus, through improvization, in this module, they faced an activity absolutely unknown to all of them, they had to leave their comfort zone, learning to react to different unexpected situations and be able to receive the opinion of the audience. The trainer for the module sought to "put into practice personal communication, the way to build a message of what you want to say, and express it in public", again, the harmony between trainers and students was observed in the attainment of the different modules.

Following the goal to develop valid skills for the future, there is a statistical relationship between the module and the perception that it provided applicable tools for the future $(\mathrm{H}(5)=21,575, p<0.001)$. Figure 2 shows that "Public Speaking", "Social Media", "Communicating Efficiently", and "Leadership Styles and Techniques" were the most appreciated modules throughout the years as the ones that most contributed to their future professional career, with values of 9.3, 9.0, 8.9, and 8.7 respectively. In fact, the minimum rate, on a 10-point scale where 10 is the best, was 6 or 7 indicating students' positive opinion of the WLDP.

However, the most important conclusion is to highlight that students did not see these skills in an isolated and disconnected way between some subjects and others, the development of the program took them through a continuous process of growth, taught them to learn for example, how to use listening in a process of communication for leadership and teamwork. Also, thanks to the development of the program with professionals who transferred knowledge from their professional experience, they were able to discover the different possible scenarios which, in a not too distant future, they would face and thus learn not only the different situations with which they would find themselves but also how to react, "what to do" as they themselves said in Focus Group 5 (third year). 


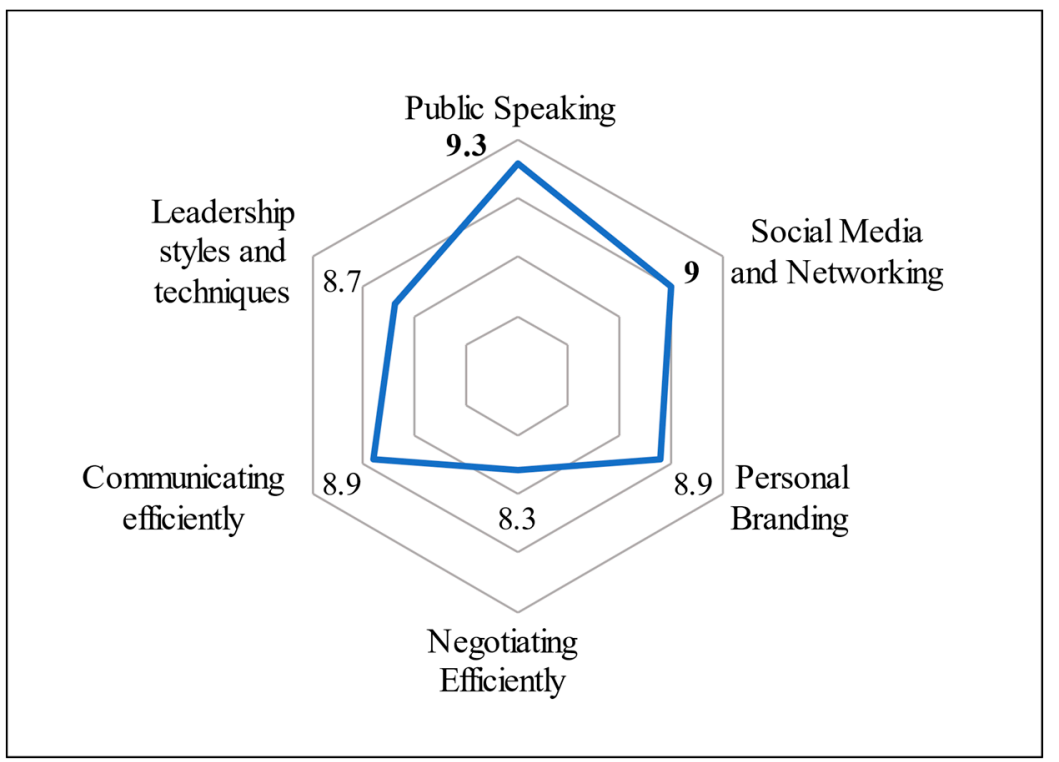

Figure 2. Descriptive results of the extent that training activities provide skills for future careers and each module (on average). Scale from 1 = Very Bad; 10 = Very Good.

\subsection{Assessment of Inner Personal Transformation}

Throughout the years, the students in the focus groups, repeatedly expressed a change in their way of perceiving themselves, in their motivations, in their confidence, in their possibilities of being leaders, as well as an increase in their ambition to be managers: "It (the course) has helped a lot on a personal level of self-esteem, motivation, confidence, the decision that you can get things if you work and others"; "Trust more in myself and in my qualities. Set a goal and know where I want to go and shoot, shoot, and shoot." (Focus Group 1, first year). The program was shown to change their attitude and see themselves as "we are unique, we can do it, I can do it" breaking down one of the main barriers highlighted by the literature is the lack of self-confidence, in women reaching managerial positions.

One step in gaining confidence was the fact that they were selected to participate in the program. Likewise, throughout the program's years, a repeated sentiment in students that progressively increased during the months the training lasted was the feeling that they were carrying out an inner reflection, sometimes difficult, whose result was a personal transformation to gaining self-knowledge and self-esteem. All 75 students expressed their sense of belonging to a "select" group in which unique knowledge, experiences and personal changes were shared. The verification of these processes made it necessary to propose an indicator that would measure the relationship between the feelings experienced by the students and the acquisition of skills and personal transformation. In the final year, emotions were measured using the Achievement Emotions Questionnaire (AEQ) scale [60].

Positive emotions predominated during and at the end of the program, with almost negligible percentages of students not feeling them. Table 6 shows that the most notable positive emotions were those of high motivation (Motivation: $91 \%$ of the students), greater hope in their own abilities (Hope b): $89 \%$ of the students) and, as a consequence, an increase in self-confidence (Hope a): $85 \%$ ). Focus groups highlighted that they were motivated throughout the program, from selection to the end. As they got to know themselves, they all highlighted that they had gained in confidence in a significant way, self-confidence based on their possibilities, aware of their weaknesses but also of their strengths. This idea was reinforced by three trainers when they explained that the students "gain confidence, security in decision making, strengthening their personality" referring to the program as a whole. An example of the high level of emotion and commitment was detailed by a trainer when she told us that "time was running out and there were four people left who had to present, I proposed finishing in the courtyard to them, they all said yes". In addition, 
gratitude was a word that appeared constantly, all the comments were always supported by some positive assessment in general or, in particular, from the deep "thanks" that we heard in the two Focus Groups repeatedly. This gratitude was also felt by the trainers who in the interviews said that they had also felt gratitude for being in the project, "the high level of gratitude is amazing" referring to comments from the students about "the luck of being in the project".

Table 6. Descriptive results of the positive emotions felt by the student's scale from 1 to $10 ; 1=$ No emotions; $10=\mathrm{A}$ lot of emotions; $\mathrm{N}=180$.

\begin{tabular}{cccccc}
\hline & Positive Emotions & Mean & ST & YES & NO \\
\hline Motivation & "I am more motivated than when I started the module" & 8.6 & 2.217 & $91 \%$ & $3 \%(n=6)$ \\
Hope b) & "I have great hope that my abilities will be sufficient for & 8.4 & 1.899 & $89 \%$ & $3 \%(n=5)$ \\
Hope a) & "I feel more self-confident on finishing the module" & 8.3 & 1.928 & $85 \%$ & $8 \%(n=3)$ \\
Enjoyment a) & "I felt excited during the module" & 8.2 & 2.012 & $86 \%$ & $7 \%(n=11)$ \\
Pride & "I am proud of how well I mastered the module" & 8.2 & 2.111 & $87 \%$ & $6 \%(n=11)$ \\
Enjoyment b) & "For me the module was a challenge that I enjoyed" & 8 & 2.207 & $83 \%$ & $8 \%(n=15)$ \\
Relief a) & "I feel very relieved during the module" & 7.9 & 2.164 & $83 \%$ & $7 \%(n=14)$ \\
\hline
\end{tabular}

NO, they have not felt it (values below than 4); YES, they have felt it (values above 6).

\section{Discussion and Conclusions}

Many efforts have been made to reduce gender imbalance in adult leadership success. Companies have mechanisms to promote equal opportunities internally, but the transformation must begin before [81]. It is necessary to tackle inequality early as one path to help bridge the leadership gender gap [82]. Therefore, fostering the leadership education of undergraduate female university students can contribute to increasing the representation of women in executive positions. Progress in this area requires a two-way cultural evolution, with a greater involvement of society in education and, especially, the search for partnerships between universities, companies, and managers, allowing the creation of WLDPs that respond to the real needs and future skills of students in their professional development $[9,47]$.

The Women Leadership Development Program (WLDP) model that is shown in this research, and its results, could provide useful insights and information for scholars, practitioners and stakeholders researching and developing WLDPs with an OI approach.

Until now, the literature has focused on presenting programs aimed at female faculty and administrative staff [32-39]. Less attention has been paid to female undergraduate students. Also, although Ericksen [42] uses students from various degrees, there is not much previous research with multidisciplinary groups. This program was only centered on female undergraduates and it was not exclusively for students from the Faculty of Business and Law, Organizer of the WLDP, as that would have been limiting. Society is complex and diverse, so the recruitment was done in collaboration with the deans and professors of other faculties so that the program was open, with multidisciplinary students: STEM and areas of Social Sciences: such as Audiovisual Communication, Advertising and Journalism.

The WLDP was based on a basic premise: to help young women overcome the two traditional barriers that have been identified in the literature as hindering women's access to managerial positions: the lack of leadership training and poor self-confidence and ambition [9,83]. In line with other leadership training programs [26,27], one of the issues most appreciated by the students on the WLDP program was that it provided them with skills for the future with immediate applicability. Also, participants said that there was a before and after the program where a transformative journey took place gaining self-confidence based on their possibilities, their strengths and also, the skill sets and toolsets they need to adjust and adapt to the work environment in the future. Emotions had a lot to do with this transformation, as the results have shown. Manager participation as a role model increased this positive effect of the motivational factors and 
expectations of success [84]. The highest rated module was "Public Speaking", which used a very disruptive methodology as it incorporated theater to develop verbal and non-verbal communication skills. This module was a turning point that had a leverage effect on the acquisition of other competencies, an improvement in their motivation and in self-confidence. The integration of business and arts-based learning has been successfully used in other courses with Collaborative Innovation at UC Berkeley, which connected personal development to diverse-team participation and leadership skills [24].

Following the collaborative design used for most similar previous programs [85], this WLDP arose initially from the alliance between the university and an association of women managers but with the intention of linking other agents. The good results of the first course made possible alliances with three other external agents in the following years (Fundación Banco de Sabadell, Caixabank, and Design for Change). All of them provided human capital, trainers, and teaching methodologies adapted to the needs of society and funding.

However, attracting external stakeholders is not enough; some research has found that the majority of leadership development programs are not effective [29]. One of the novelties of the program is that it not only included these stakeholders, but the model was developed with an OI approach that allowed for the establishment of a whole ecosystem which brought together knowledge and experience in leadership as well as adult training $[29,86]$. This co-creation process is an opportunity to build shared knowledge and facilitate its transfer with the active participation of everyone in the training process, in addition to establishing an ecosystem of permanent collaboration and an effective way of attracting talent.

Prior WLDPs have used various evaluation methodologies, especially analysis before and at the end of the course, through self-reports by the participants (surveys, journals), mentoring analyses, focus groups, in-depth interviews $[34,37-39,46]$ and to a lesser extent by doing post-training follow-ups applied to the labor market $[77,87,88]$. The evaluation of these programs has focused on measuring the effectiveness of the course through the acquired leadership skills and satisfaction [35,38,39] and affective reactions [46] considered from the perspective of Emotional Intelligence [89]. Less attention has been paid to aspects such as the emotions of the students and trainers during the course $[43,47]$. On the other hand, studies combining diverse evaluation methodologies are scarce; in fact, many of the studies use only qualitative ones $[27,28,43-45]$ and others only quantitative $[25,26]$, even though the literature on leadership programs has already highlighted the importance of triangular evaluation [30,46]. Hence, our approach to the leadership program assessment included a comprehensive holistic methodology $[30,52,53]$ using a study design with qualitative and quantitative techniques and diverse informants. It facilitated the comparability of data obtained by different methods allowing cross-validation when the results were similar in both. The two informants in the program assessment (students and the trainers) permitted a $360^{\circ}$ evaluation. This design is in line with the open innovation approach [86].

In summary, the innovations in this WLDP are: (i) the participation of the stakeholders in the whole process (idea, design, implementation, evaluation); (ii) the incorporation de multidisciplinary female undergraduates students; (iii) the open innovation approach with an active methodology and the 360-degree evaluation that; (iv) allowed a wide range of improvements to be made in a continuous cycle throughout the years, explaining the success of the program's results. Consequently, the model presented in this WLDP case study could be used as a guide for scholars and practitioners and could be useful for its implementation in universities and companies.

The EU urges universities to place students and their learning at the center of the educational process so that they can effectively develop their capabilities. Cooperation between universities and their stakeholders brings value to all. The findings from this study are consistent with investigations that found that the collaboration of society, stakeholders, and industry is necessary so that innovation also occurs in educational environments and students acquire innovative thinking behavior $[22,25,27]$. However, practically, universitybusiness cooperation remains reduced to initiatives basically focused on applied research, in very specific areas, with no implications for teaching [90]. For this reason, initiatives 
such as the WLDP presented in this paper with its four innovation axes are a real example that this cooperation can exist and can serve as a model to be applied in other similar programs. This program is complementary to the undergraduate curriculum, which permits overcoming the rigidities of the educational system, in addition to incorporating multidisciplinary students that brings them closer to a more diverse reality similar to the one they will find in the labor market, thus enriching the training process. In short, the course improves the educational offer of the university, which is usually slow to react to the constant changes in the labor market [91].

Turning to the limitations of the research: as a case study, this paper provides an indepth real-life phenomenon analysis within a specific environmental context. Nevertheless, it has the limitations of this kind of methodology as there is no random sampling and the sample does not represent a large enough population to back up the validity of the findings [50].

Another limitation of our study is that we do not know the impact of the WLDP on the professional careers of the students, although it is true that it will be necessary to wait for some time for them to have been in the labor market for a few years. Future research will try to measure the impact of the WLDP through a follow-up of the young women on their professional performance in the labor market $[46,47]$.

In this study, the benefits for both the university and the students of the WDLP are analyzed. It would be interesting to extend the research and find out how important the role of the university in the implementation of these leadership programs is for the stakeholders. Our research already indicates that companies that have participated in this program have used it as a source of talent recruitment. In the future, it would be interesting to delve deeper into the benefits for our stakeholders, for example, in terms of economics, reputation, and engagement [92], as well as the way that this cooperation can be sustained over time.

Author Contributions: Conceptualization, P.L.-S., M.S.-P., C.d.1.F.-C., and A.M.V.-P.; Methodology, P.L.-S., M.S.-P., C.d.1.F.-C., and A.M.V.-P.; Software, M.S.-P.; Formal analysis, P.L.-S., M.S.-P., C.d.l.F.C., and A.M.V.-P.; Investigation, P.L.-S., M.S.-P., C.d.1.F.-C., and A.M.V.-P.; Writing-original draft preparation, P.L.-S., M.S.-P., C.d.1.F.-C., and A.M.V.-P.; Writing review, P.L.-S., M.S.-P., C.d.1.F.-C., and A.M.V.-P.; Editing, A.M.V.-P. and C.d.1.F.-C., Funding acquisition, P.L.-S. All authors have read and agreed to the published version of the manuscript.

Funding: The Women's Leadership Development Program received funding from the Permanent Seminar of Entrepreneurs and Leader Undergraduate Students (Agreement between Universidad Rey Juan Carlos and CAIXABANK. Code: 2015/00235/001. Reference: V540).

Institutional Review Board Statement: Not applicable.

Informed Consent Statement: Informed consent was obtained from all subjects involved in the study.

Data Availability Statement: Restrictions apply to the availability of these data. Data was obtained from students and trainers and are available from the authors with the permission of participants.

Acknowledgments: The authors would like to express their gratitude to Women CEO's support, to the students and lecturers who participated in this study for their selfless collaboration. Obra Social La Caixa for the funding to carry out the third edition of this program and Design for Change for the ad hoc design of the final program' module.

Conflicts of Interest: The authors declare no conflict of interest.

\section{References}

1. Catalyst Pyramid: Women in S\&P 500 Companies । Catalyst. Available online: https://www.catalyst.org/research/women-insp-500-companies / (accessed on 14 May 2021).

2. International Labour Organization. ILO Monitor: COVID-19 and the World of Work. Fifth Edition. Available online: https: //www.ilo.org/wcmsp5/groups/public/@dgreports/@dcomm/documents/briefingnote/wcms_749399.pdf (accessed on 13 April 2021). 
3. World Economic Forum. The Future of Jobs Report. 2020. Available online: http://www3.weforum.org/docs/WEF_Future_of_ Jobs_2020.pdf (accessed on 13 April 2021).

4. Hopkins, M.M.; O'Neil, D.A. Authentic leadership: Application to women leaders. Front. Psychol. 2015, 6, 5. [CrossRef] [PubMed]

5. Baxter, J.; Wright, E.O. The glass ceiling hypothesis: A comparative study of the United States, Sweden, and Australia. Gend. Soc. 2000, 14, 275-294. [CrossRef]

6. Matheson, I.; Lyle, E. Gender Bias in Canadian Military Leadership Training. J. Ethnogr. Qual. Res. 2017, 12, 18-28.

7. European Commission/EACEA/Eurydice. The European Higher Education Area in 2018: Bologna Process Implementation Report. Available online: http:/ / ec.europa.eu/eurydice (accessed on 13 April 2021).

8. European Commission. Sustainable development in the European Union. Monitoring Report on Progress towards the SDGs in an EU Context. Available online: https:/ / ec.europa.eu/eurostat/web/products-statistical-books/-/KS-02-20-202 (accessed on 13 April 2021).

9. Debebe, G.; Anderson, D.; Bilimoria, D.; Vinnicombe, S.M. Women's Leadership Development Programs: Lessons Learned and New Frontiers. J. Manag. Educ. 2016, 40, 231-252. [CrossRef]

10. Chesbrough, H. Open Innovation-The New Imperative for Creating and Profiting from Technology; Harvard Business School Publishing: Boston, MA, USA, 2003; ISBN 9781578518371.

11. Bruns, H.C. Working alone together: Coordination in collaboration across domains of expertise. Acad. Manag. J. 2013, 56. [CrossRef]

12. Day, D.V.; Dragoni, L. Leadership Development: An Outcome-Oriented Review Based on Time and Levels of Analyses. Annu. Rev. Organ. Psychol. Organ. Behav. 2015, 2, 133-156. [CrossRef]

13. de las Heras-Rosas, C.; Herrera, J. Research trends in open innovation and the role of the university. J. Open Innov. Technol. Mark. Complex. 2021, 7, 29. [CrossRef]

14. Huggins, R.; Prokop, D.; Thompson, P. Universities and open innovation: The determinants of network centrality. J. Technol. Transf. 2020, 45, 718-757. [CrossRef]

15. Hossain, M.; Anees-ur-Rehman, M. Open innovation: An analysis of twelve years of research. Strateg. Outsourcing 2016, 9, $22-37$. [CrossRef]

16. Howells, J.; Ramlogan, R.; Cheng, S.L. Universities in an open innovation system: A UK perspective. Int. J. Entrep. Behav. Res. 2012, 18, 440-456. [CrossRef]

17. Sánchez, P.I.; de las Heras Pedrosa, C.; Jambrino-Maldonado, C. Innovación abierta en entornos educativos. Opcion 2015, 31, 602-616. [CrossRef]

18. David, B.; Gillian, C. Complexity Theory and the Social Sciences: The State of the Art, 1st ed.; Routledge: London, UK, 2013; ISBN 9780415693684.

19. Poutanen, P.; Soliman, W.; Ståhle, P. The complexity of innovation: An assessment and review of the complexity perspective. Eur. J. Innov. Manag. 2016, 19. [CrossRef]

20. Karlsson, C.; Warda, P. Entrepreneurship and innovation networks. Small Bus. Econ. 2014, 43, 393-398. [CrossRef]

21. Choi, J.I.; Markham, S. Creating a corporate entrepreneurial ecosystem: The case of entrepreneurship education in the RTP, USA. J. Open Innov. Technol. Mark. Complex. 2019, 5, 62. [CrossRef]

22. Iglesias-Sánchez, P.P.; Jambrino-Maldonado, C.; de las Heras-Pedrosa, C. Training entrepreneurial competences with open innovation paradigm in higher education. Sustainability 2019, 11, 4689. [CrossRef]

23. Morales-Alonso, G.; Pablo-Lerchundi, I.; Vargas-Perez, A.M. An Empirical Study on the Antecedents of Knowledge Intensive Entrepreneurship. Int. J. Innov. Technol. Manag. 2016, 13, 1640011. [CrossRef]

24. Beckman, S.; Scott, S.J.; Wymore, L. Collaborative innovation: Exploring the intersections among theater, art and business in the classroom. J. Open Innov. Technol. Mark. Complex. 2018, 4, 52. [CrossRef]

25. Kuo, A.A.; Verdugo, B.; Holmes, F.J.; Henry, K.A.; Vo, J.H.; Perez, V.H.; Inkelas, M.; Guerrero, A.D. Creating an MCH Pipeline for Disadvantaged Undergraduate Students. Matern. Child Health J. 2015, 19, 2111-2118. [CrossRef]

26. Grantham, S.; Pidano, A.E.; Whitcomb, J.M. Female graduate students' attitudes after leadership training: A case study. J. Leadersh Stud. 2014, 8, 6-16. [CrossRef]

27. Cline, L.L.; Rosson, H. Exploring the Unique Challenges and Opportunities of Female Leaders within the Agricultural Industry: A Panel Discussion. J. Leadersh. Educ. 2019, 18, 130. [CrossRef]

28. Shollen, S.L. Teaching and learning about women and leadership: Students' expectations and experiences. J. Leadersh. Educ. 2015, 14, 35-52. [CrossRef]

29. Madsen, S.R.; Andrade, M.S. Unconscious Gender Bias: Implications for Women's Leadership Development. J. Leadersh. Stud. 2018, 12, 62-67. [CrossRef]

30. Ely, R.J.; Ibarra, H.; Kolb, D.M. Taking gender into account: Theory and design for women's leadership development programs. Acad. Manag. Learn. Educ. 2012, 10, 474-493. [CrossRef]

31. Nash, M.; Moore, R. 'When I look in the bathroom mirror, I see all the women standing behind me': An evaluation of a leadership development program for women in STEMM. J. Sociol. 2020. [CrossRef]

32. Madsen, S. Handbook of Research on Gender and Leadership; Edward Elgar Publishing: Chelteham, UK, 2017 ; ISBN 9781785363863.

33. Bierema, L.L. No woman left behind: Critical leadership development to build gender consciousness and transform organizations. In Handbook of Research on Gender and Leadership; Edward Elgar Publishing: Chelteham, UK, 2017; pp. $145-162$. 
34. Brabazon, T.; Schulz, S. Braving the bull: Women, mentoring and leadership in higher education. Gend. Educ. 2020, 32, 873-890. [CrossRef]

35. Levine, R.B.; González-Fernández, M.; Bodurtha, J.; Skarupski, K.A.; Fivush, B. Implementation and evaluation of the Johns Hopkins University School of Medicine Leadership Program for Women Faculty. J. Women's Health 2015, 24, 360-366. [CrossRef]

36. White, J.S. HERS Institutes: Curriculum for advancing women leaders in higher education. Adv. Dev. Hum. Resour. 2012, 14, 11-27. [CrossRef]

37. Barnard, D.S.; Arnold, J.; Bosley, S.; Munir, F. Onwards and Upwards? Tracking Women's Work Experiences in Higher Education. Available online: www.jcbarlow.com/ (accessed on 13 April 2021).

38. Harris, C.A.; Leberman, S.I. Leadership development for women in New Zealand universities: Learning from the New Zealand women in leadership program. Adv. Dev. Hum. Resour. 2012, 14, 28-44. [CrossRef]

39. Peterson, H. A women-only leadership development program: Facilitating access to authority for women in Swedish higher education? Soc. Sci. 2019, 8, 14. [CrossRef]

40. Selzer, R.; Howton, A.; Wallace, F. Rethinking Women's Leadership Development: Voices from the Trenches. Adm. Sci. 2017, 7, 18. [CrossRef]

41. Knipfer, K.; Shaughnessy, B.; Hentschel, T.; Schmid, E. Unlocking Women's Leadership Potential: A Curricular Example for Developing Female Leaders in Academia. J. Manag. Educ. 2017, 41, 272-302. [CrossRef]

42. Ericksen, K.S. An Evaluation of the Long-Term Effectiveness of a Women' s Leadership Development Program. Available online: https:/ / core.ac.uk/download/pdf/227561228.pdf (accessed on 15 May 2021).

43. Brue, K.; Brue, S. Experiences and outcomes of a women's leadership development program: A phenomenological investigation. J. Leadersh. Educ. 2016, 15, 75-97. [CrossRef]

44. Shollen, S.L. Cultivating Intellectual Safety in a Women and Leadership Course. J. Leadersh. Educ. 2016, 15, 1-10. [CrossRef]

45. Brue, K.; Brue, S. Leadership Role Identity Construction in Women's Leadership Development Programs. J. Leadersh. Educ. 2018, 17, 7-27. [CrossRef]

46. Reyes, D.L.; Dinh, J.; Lacerenza, C.N.; Marlow, S.L.; Joseph, D.L.; Salas, E. The state of higher education leadership development program evaluation: A meta-analysis, critical review, and recommendations. Leadersh. Q. 2019, 30, 101311. [CrossRef]

47. Lacerenza, C.N.; Reyes, D.L.; Marlow, S.L.; Joseph, D.L.; Salas, E. Leadership Training Design, Delivery, and Implementation: A Meta-Analysis. J. Appl. Psychol. 2017, 102, 1686-1718. [CrossRef]

48. Schwab, D.P. Research Methods for Organization Studies, 2nd ed.; Lawrence Erlbaum Associates, Inc.: Mahwah, NJ, USA, 2005; ISBN 0-8058-4727-8.

49. Yin, R.K. Case Study Research. Design and Methods, 5th ed.; Sage Publications: Thousand Oaks, CA, USA; London, UK, 2014; ISBN 9781452242569.

50. Ridder, H.G. The theory contribution of case study research designs. Bus. Res. 2017, 10, 281-305. [CrossRef]

51. Kallemeyn, L.M.; Hall, J.N.; Gates, E. Exploring the Relevance of Complexity Theory for Mixed Methods Research. J. Mix. Methods Res. 2020, 14, 288-304. [CrossRef]

52. Denzin, N. The Research Act: A Theoretical Introduction to Sociological Methods; Transaction Publishers: Piscataway, NJ, USA, 2017; ISBN 9780202368597.

53. Fusch, P.; Fusch, G.E.; Ness, L.R. Denzin's paradigm shift: Revisiting triangulation. Denzin's Paradig. Shift Revisiting Triangulation 2018, 10, 19-32. [CrossRef]

54. Creswell, J.W.; Plano Clark, V.L. Designing and Conducting Mixed Methods Research, 2nd ed.; Sage: Thousand Oaks, CA, USA, 2011; ISBN 978-1412975179.

55. Jacob, B.; Hofmann, F.; Stephan, M.; Fuchs, K.; Markus, S.; Gläser-Zikuda, M. Students' achievement emotions in university courses-does the teaching approach matter? Stud. High. Educ. 2019, 44, 1768-1780. [CrossRef]

56. Janson, A. Extracting leadership knowledge from formative experiences. Leadership 2008, 4, 73-94. [CrossRef]

57. Waller, L.; Reitz, M.; Poole, E.; Riddell, P.M.; Muir, A. Experiential learning as preparation for leadership: An exploration of the cognitive and physiological processes. Leadersh. Organ. Dev. J. 2017, 38, 513-529. [CrossRef]

58. Villegas, E.; Raffaelli, M. Experiencing and Learning About Emotions: A Longitudinal Analysis of Youth Program Participants. J. Youth Adolesc. 2018, 47, 1684-1696. [CrossRef] [PubMed]

59. Segovia-Pérez, M.; Laguna-Sánchez, P.; de la Fuente-Cabrero, C. Education for sustainable leadership: Fostering women's empowerment at the University Level. Sustainability 2019, 11, 5555. [CrossRef]

60. Pekrun, R.; Goetz, T.; Frenzel, A.C.; Barchfeld, P.; Perry, R.P. Measuring emotions in students' learning and performance: The Achievement Emotions Questionnaire (AEQ). Contemp. Educ. Psychol. 2011, 36, 36-48. [CrossRef]

61. Hsieh, H.F.; Shannon, S.E. Three approaches to qualitative content analysis. Qual. Health Res. 2005, 15. [CrossRef]

62. Miles, M.B.; Huberman, A.M.; Johnny, S. Qualitative Data Analysis a Methods Sourcebook, 4th ed.; SAGE Publications, Inc.: Thousand Oaks, CA, USA, 2019; ISBN 9781506353074.

63. Design for Change España Nuestro método I Design for Change España. Available online: https://dfcspain.org/nuestrometodo/ (accessed on 14 March 2021).

64. Skalicky, J.; Warr Pedersen, K.; van der Meer, J.; Fuglsang, S.; Dawson, P.; Stewart, S. A framework for developing and supporting student leadership in higher education. Stud. High. Educ. 2020, 45, 100-116. [CrossRef] 
65. European Commission-General for Employment, S.A.I. Transferability of Skills across Economic Sectors-Publications Office of the EU. Available online: https:/ / op.europa.eu/en/publication-detail/-/publication/21d614b0-5da2-41e9-b71d-1cb470fa9789\# document-info (accessed on 13 April 2021).

66. OECD-KRIVET Group of National Experts on Vocational Education and Training Integrated Use of Occupational and Personal Skills for Lifelong Vocational Education in Korea. Available online: https://www.oecd.org/officialdocuments/ publicdisplaydocumentpdf/?cote=EDU/EDPC/VET\%282012\%291\&docLanguage=En (accessed on 13 April 2021).

67. UNESCO-IBE Glossary of Curriculum Terminology UNESCO International Bureau of Education. Available online: http:/ /www. ibe.unesco.org/fileadmin/user_upload/Publications/drafts/IBE_curriculum_glossary_final.pdf (accessed on 13 April 2021).

68. Gabor, M.R.; Blaga, P.; Matis, C. Supporting employability by a skills assessment innovative tool-Sustainable transnational insights from employers. Sustainability 2019, 11, 3360. [CrossRef]

69. Laguna-Sánchez, P.; Abad, P.; de la Fuente-Cabrero, C.; Calero, R. A university training programme for acquiring entrepreneurial and transversal employability skills, a students' assessment. Sustainability 2020, 12, 796. [CrossRef]

70. Dunn, D.; Gerlach, J.; Hyle, A. Gender and Leadership: Reflections of Women in Higher Education Administration. Int. J. Leadersh Chang. 2014, 2, 2.

71. Baepler, P.; Walker, J.D.; Driessen, M. It's not about seat time: Blending, flipping, and efficiency in active learning classrooms. Comput. Educ. 2014, 78, 227-236. [CrossRef]

72. Dul, J.; Hak, T. Case Study Methodology in Business Research; Routledge: London, UK, 2007; ISBN 9780080552194.

73. Imagine Creativity Center Imagine Creativity Center. Available online: https://imagine.cc/projects/ (accessed on 9 April 2021).

74. Flanagan, J.C. The critical incident technique. Psychol. Bull. 1954, 51, 327. [CrossRef] [PubMed]

75. United Nations Transforming Our World: The 2030 Agenda For Sustainable Development. Available online: https: //sustainabledevelopment.un.org/content/documents/21252030.Agenda.forSustainable.Development.web.pdf (accessed on 15 April 2021).

76. García-Rodríguez, F.J.; Gil-Soto, E.; Ruiz-Rosa, I. New Methods in University Entrepreneurship Education: A Multidisciplinary Teams Approach. Creat. Educ. 2012, 03, 878-883. [CrossRef]

77. Brue, K. Harmony and Help: Recognizing the Impact of Work-Life Balance for Women Leaders. J. Leadersh. Educ. 2018, 17, 219-243. [CrossRef]

78. Brown, T.; Katz, B. Change by design. J. Prod. Innov. Manag. 2011, 28, 381-383. [CrossRef]

79. Goleman, D. The Focused Leader: How effective executives direct their own-And their organizations'-Attention. Harv. Bus. Rev. 2013, 51-60. Available online: https:/ / hbr.org/2013/12/the-focused-leader (accessed on 13 April 2021).

80. Alastruey, R. El Networking, 33rd ed.; UOC Editorial: Barcelona, Spain, 2010; ISBN 978-84-9788-111-1.

81. Chisholm-Burns, M.A.; Spivey, C.A.; Hagemann, T.; Josephson, M.A. Women in leadership and the bewildering glass ceiling. Am. J. Health Pharm. 2017, 74, 312-324. [CrossRef]

82. Eva, N.; De Cieri, H.; Murphy, S.E.; Lowe, K.B. Leader development for adolescent girls: State of the field and a framework for moving forward. Leadersh. Q. 2021, 32. [CrossRef]

83. Sugiyama, K.; Cavanagh, K.V.; van Esch, C.; Bilimoria, D.; Brown, C. Inclusive Leadership Development: Drawing From Pedagogies of Women's and General Leadership Development Programs. J. Manag. Educ. 2016, 40, 253-292. [CrossRef]

84. Clarke, M. Advancing women's careers through leadership development programs. Empl. Relat. 2011, 33, 498-515. [CrossRef]

85. Ollila, S.; Yström, A. Exploring Design Principles of Organizing for Collaborative Innovation: The Case of an Open Innovation Initiative. Creat. Innov. Manag. 2016, 25. [CrossRef]

86. Dingli, S.; Landy, M. Open Innovation Curricula: Key Indicators and Success Factors. In Innovation Education Reloaded: Nurturing Skills for the Future: The Open Innovation Handbook; Mention, A.-L., Nagel, A.P., Hafkesbrink, J., Dabrowska, J., Eds.; LUT Scientific and Expertise Publications: Lappeenranta, Finland, 2016; Volume 66, pp. 79-88. ISBN 978-952-335-033-5.

87. Bullough, A.; De Luque, M.S.; Abdelzaher, D.; Heim, W. Developing women leaders through entrepreneurship education and training. Acad. Manag. Perspect. 2015, 29, 250-270. [CrossRef]

88. Egan, J.; Sergi McBrayer, J.; Tolman, S.; Wells, P. Exploring Alumni Valuation of an Undergraduate Leadership Program. J. Leadersh. Educ. 2019, 19, 68-86. [CrossRef]

89. Goleman, D. Emotional Intelligence; Bantam Books: New York, NY, USA, 1995.

90. European Commission. Communication from the Commission to the European Parliament, the Council, the European Economic and Social Committee and the Committee of the Regions. Available online: https:/ / eur-lex.europa.eu/legal-content/EN/ALL/ ?uri=COM\%3A2017\%3A247\%3AFIN (accessed on 12 April 2021).

91. Cai, Y. From an analytical framework for understanding the innovation process in higher education to an emerging research field of innovations in higher education. Rev. High. Educ. 2017, 40. [CrossRef]

92. Tsinopoulos, C.; Sousa, C.M.P.; Yan, J. Process Innovation: Open Innovation and the Moderating Role of the Motivation to Achieve Legitimacy. J. Prod. Innov. Manag. 2018, 35. [CrossRef] 